\title{
The Effect of Green Betel Leaves (Piper betle L.) Extract on Wounding Healing in Mice (Mus musculus L.)
}

\author{
Nurul Atika Zar'ah ${ }^{{ }^{*}}$, Syachruddin ${ }^{1}$, Hj. Kusmiyati ${ }^{1}$ \\ ${ }^{1}$ Program Studi Pendidikan Biologi FKIP Universitas Mataram, Mataram, Indonesia
}

\author{
Article History \\ Received : December $16^{\text {th }}, 2020$ \\ Revised : January $07^{\text {th }}, 2021$ \\ Accepted : January $18^{\text {th }}, 2021$ \\ Published : January $23^{\text {th }}, 2021$ \\ *Corresponding Author: \\ Nurul Atika Zar'ah, \\ Program Studi Pendidikan \\ Biologi FKIP Universitas \\ Mataram, Mataram, Indonesia \\ Email: aatika269@gmail.com
}

\begin{abstract}
Green betel leaf (Piper betle L.) contains secondary metabolites, namely alkaloids, flavonoids, steroids, terpenoids, saponins, tannins. Green betel leaf (Piper betle L.) is widely used for wound healing, especially in rural Indonesians. This study aims to determine the effect of green betel leaves extract (Piper betle L.) on wound healing in mice (Mus musculus L.). The samples were determined using a randomized block design (RBD) using mice (Mus musculus L.) which consisted of three treatment groups using a concentration of $20 \%, 30 \%, 40 \%$ and one control group. The Measure of the average diameter of the wound was using a ruler on each side of the diameter. The data measurement for the average diameter of wound restriction was analyzed by using the one way. The one way Anova test showed that the sig or p-value is $0.000<0.05$ (at the alpha level of $5 \%$ ) so that Ho is rejected which indicates that there is an effect of giving green betel leaf extract (Piper betel L.) on wound healing in mice (Mus musculus $L$.). Based on the results of the LSD or LSD test, it shows that it is not significant / the same because the sig value is $0.074>0.05$, which means that no change occurs in mice when given $30 \%$ or $40 \%$ extract. Green betel leaf extract (Piper betle L.) has an effect on wound healing in mice (Mus musculus L.).
\end{abstract}

Keywords: Green Betel Leaves, Diameter, Wound Restriction

\section{Pendahuluan}

Obat tradisional memiliki keragaman fungsi, diantaranya adalah untuk penyembuhan luka menggunakan bahan baku obat tradisional umumnya dari tumbuh-tumbuhan, dan jenis tumbuhan yang memiliki khasiat untuk penyembuhan luka adalah tumbuhan sirih hijau (Piper betle L.) Jenis tumbuhan ini memiliki banyak khasiat untuk mengobati berbagai penyakit dan telah dimanfaatkan oleh masyarakat (Oswald, 1981). Tanaman daun sirih hijau berkhasiat untuk mengobati penyakit katagiri ringan sampai berat (Hidayat, 2015). Tanaman daun sirih itu dapat digunakan untuk obat luka pada kulit, obat bisul, hidung berdarah, radang selaput lendir mata, bau mulut, menghentikan gusi berdarah (Prayoga, 2013). Selanjutnya Masir (2012) menyebutkan bahwa pengaruh ekstrak daun sirih terhadap penyembuhan luka laserasi. Dalam hal ini khasiat daun sirih sebagai obat dapat bersumber dari produksi senyawa metabolit sekunder yang meliputi alkaloid, flavovoid, steroid, terpenoid, saponin, dan tanin (Acar, 2002)

Saat sekarang ini, masyarakat sering berhadapan dengan keterbatasan obat yang tersedia secara medis, terutama untuk pengobatan akibat luka pada organ tubuh. Kondisi luka yang ditemukan dari banyaknya kasus, seringkali memasuki kondisi inflamasi patologis karena proses pengobatan yang tertunda (Mawarti, 2016). Waktu penyembuhan luka dapat ditentukan dengan membedakan dari jenis luka yang terjadi pada bagian kulit ataupun kedalaman dari luka (Hasibuan, 2018). Oleh karena itu, pemanfaatan tumbuhan yang banyak tersedia, seperti daun sirih hijau (Piper betle L.) dapat menjadi solusi dalam penanganan luka sejak dini. Penilaian khasiat penyembuhan luka dengan bahan baku daun sirih hijau (Piper betle L.) untuk uji efektivitas dapat menggunakan hewan mencit (Mus musculus L.) yang banyak digunakan untuk percobaan (Haki, 
2009). Mencit (Mus musculus L.) memiliki keunggulan berdasarkan karakteristik genetik, biologi, dan perilaku yang memiliki kemiripan dengan manusia (Fransius, 2008).

Sementara itu, potensi daun sirih hijau (Piper betle L.) sebagai obat herbal belum banyak dimanfaatkan. Selain itu, tumbuhan daun sirih hijau sudah dikenal secara tradisional atau turun temurun oleh masyarakat Indonesia. Namun demikian, penelitian tentang keragaman khasiat daun sirih hijau (Piper betle L.) khususnya sebagai obat luka. Oleh karena itu perlu dilakukan penelitian tentang khasiat daun sirih hijau sebagai objek percobaan. Hasil penelitian ini dapat bermanfaat sumber informasi obat penyembuhan luka yang bersumber dari tumbuhan sirih, khususnys Adaun sirih hijau (Piper betle L.).

\section{Bahan dan Metode}

Penelitian eksperimental dengan rancangan penelitian menggunakan Rancangan Acak Kelompok $(R A K)$. Penelitian dilakukan pada bulan Agustus-September 2020 di Laboratorium Kimia dan Biologi FKIP Universitas Mataram. Pada penelitian ini komposisi jumlah mencit dalam desain eksperimennya (Tabel 1).

Tabel 1. Desain eksperimen komposisi jumlah hewan control dan eksperimen

\begin{tabular}{|l|c|}
\hline \multicolumn{1}{|c|}{$\begin{array}{c}\text { Perlakuan pada } \\
\text { Hewan }\end{array}$} & $\begin{array}{c}\text { Jumlah Mencit } \\
\text { (Ekor) }\end{array}$ \\
\hline Kelompok kontrol & 4 \\
\hline $\begin{array}{l}\text { Kelompok } \\
\text { Eskperimen 1 }\end{array}$ & 4 \\
\hline $\begin{array}{l}\text { Kelompok } \\
\text { Eskperimen 2 }\end{array}$ & 4 \\
\hline $\begin{array}{l}\text { Kelompok } \\
\text { Eskperimen 3 }\end{array}$ & 4 \\
\hline Jumlah & $\mathbf{1 6}$ \\
\hline
\end{tabular}

Daun sirih hijau diiris dan dikeringkan selama satu minggu. Selanjutnya, dalam proses pengeringannya dilakukan pada tempat terbuka dan tidak terkena sinar matahari secara langsung. Daun sirih hijau yang telah kering selanjutnya di blender sampai berbentuk serbuk kering, direndam (maserasi) dengan etanol 95\% selama tiga hari. Bahan cair dari hasil perendaman diperoleh dengan penyaringan dengan kertas saring. Selanjutnya hasil penyaringan diuapkan dengan Vacum rotary evaporator untuk mendapatkan ekstrak etanol daun sirih hijau dengan konsentrasi $20 \%$, 30\%, dan $40 \%$.

Metode yang digunakan dalam pembuatan luka adalah metode Morton yang telah dimodifikasi (Gitarja, 2008). Bagian hewan uji coba dilukai adalah bagian dorsolateral thoracic (bagian punggung). Langkah awal pembentukan luka adalah dengan melakukan pembersihan atau pencukuran rambut di sekitar daerah dorsolateral thoracic yang akan dibuat luka, kemudian mencit dibius dengan menggunakan clorofom. Daerah yang akan dibuat luka berbentuk lingkaran dengan diameter $2 \mathrm{~cm}$ dengan kedalaman sampai pada bagian dermis, cara mengangkat kulit menggunakan pinset dan digunting sampai bagian dermis dan jaringan ikat.

Perlakukan terhadap kelomok hewan eksperimen dilakukan dengan memberikan ekstrak daun sirih hijau (Piper betle L.) pada permukaan luka. Dalam hal ini, volume yang diberikan pada setiap kelompok perlakuan adalah sama yaitu \pm 3 tetes untuk setiap hewan uji. Sementara itu, bagian luka hewan mencit sebagai kelompok eksperimen dibalut dengan menggunakan kasa steril. Proses berikutnya adalah melakukan pengamatan pada bagian atau daerah luka secara makroskopis yaitu pengamatan diameter retriksi luka. Berkaitan dengan objek eksperimen yaitu tingkat penyembuhan ditentukan berdasarkan luas retriksi luka, luka kering (tidak bernanah) dan tidak bengkak pada bagian atau lokasi sekitar luka. Dalam hal ini, indikatornya adalah dengan ciri warna semakin hitam (warna keropeng), bahkan sampai lepas keropeng sebagai pengaruh dari pemberian ekstrak daun sirih hijau. Selanjutnya. Perlakukan untuk tiga kelompok eksperimen 
(Tabel 1) dibnerikan konsentarasi 20\%, 30\%, dan $40 \%$. Selanjutnya, parameter yang diamati setelah pemberian konsentari bahan cairan daun sirih hijau adalah melakukan pengukuran diameter dengan ukuran meli meter (mm) pada daerah luka sampai hari ke 14.

Data hasil pengukuran, selanjutnya dianalisis dengan cara menghitung rata-rata diameter luka yang diperoleh setiap hari, dengan formula, yakni diameter luka setiap hari:

$\mathrm{Dx}=\frac{d x(1)+d x(2)+d x(3)+d x(4)}{4}$

(Suratman, 1996)

Keterangan :

$\mathrm{dx}$ : Diameter luka hari ke $\mathrm{x}$ (dalam mm)

$\mathrm{dx}(1),(2),(3)$, dan (4) : Diameter luka diukur dalam berbagai arah

Setelah hasil diameter luka didapat kemudian dilakukan perhitungan persentase penyembuhan luka dengan menggunakan rumus persentase sebagai berikut:

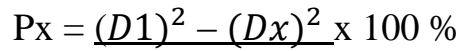
$(D 1)^{2}$

(Suratman, 1996)

Keterangan:

$\mathrm{Px}=$ Persentase penyembuhan luka hari ke $\mathrm{x}$
D1 = Diameter luka hari pertama

Dx $=$ Diameter luka pada hari ke- $\mathrm{x}$

Selain itu, analisis data dilakukan secara deskriptif. Selanjutnya, dilakukan analisis statistik dengan menggunakan Uji One-way anova yaitu untuk mengetahui adanya pengaruh ekstrak daun sirih hijau terhadap tingkat kesembuhan luka mencit (Mus musculus L.), pada tingkat kepercayaan $95 \%$ dengan signifikan. Analisis data dibantu dengan menggunakan SPSS 16,0.

\section{Hasil dan Pembahasan}

\section{Hasil Pengukuran Retriksi Luka}

Hasil pengukuran pengaruh konsentrasi ekstrak daun sirih hijau (Piper betle L.) terhadap penyembuhan luka pada mencit (Mus musculus L.) selama penelitian (Tabel 2). Hasil eksperimen menunjukkan, dimana ditemukan empat hewan uji yang memiliki nilai rata-rata retriksi luka yang berbeda. Hal ini dapat disebabkan oleh proses penyembuhan pada luka, sebagai akibat konsentrasi obat, seperti konsentrasi dari ekstrak daun sirih hijau yang diberikan. Masir (2012) menyebutkan bahwa tingkat penyembuhan luka dapat dinilai berdasarkan perubahan retriksi jaringan pada luka.

Tabel 2. Rata - Rata Retriksi Luka pada Mencit (Mus musculus L.) Desciptives

\begin{tabular}{|l|c|c|c|c|c|c|c|c|}
\hline \multicolumn{1}{|c|}{ Nilai } & $\mathbf{N}$ & Mean & Std.Deviation & $\begin{array}{c}\text { Std. } \\
\text { Error }\end{array}$ & \multicolumn{2}{|c|}{$\begin{array}{c}\text { 95\% Confidence } \\
\text { interval for } \\
\text { Mean }\end{array}$} & Minimum & Maksimum \\
\cline { 1 - 5 } & & & & & $\begin{array}{r}\text { Lower } \\
\text { Bound }\end{array}$ & $\begin{array}{c}\text { Upper } \\
\text { Bound }\end{array}$ & & \\
\hline $\begin{array}{l}\text { Diberikan } \\
\text { Aquadest }\end{array}$ & 4 & 1.6014 & .05317 & .02659 & 1.5168 & 1.6860 & 1.55 & 1.67 \\
\hline $\begin{array}{l}\text { Ekstrak } \\
20 \%\end{array}$ & 4 & 1.6509 & .03173 & .01587 & 1.6004 & 1.7014 & 1.61 & 1.68 \\
\hline $\begin{array}{l}\text { Ekstrak } \\
30 \%\end{array}$ & 4 & 1.8502 & .02205 & .01102 & 1.8151 & 1.8853 & 1.83 & 1.88 \\
\hline $\begin{array}{l}\text { Ekstrak } \\
40 \%\end{array}$ & 4 & 1.7836 & .02834 & .01417 & 1.7385 & 1.8287 & 1.75 & 1.81 \\
\hline Total & $\mathbf{1 6}$ & $\mathbf{1 . 7 2 1 5}$ & $\mathbf{. 1 0 7 9 0}$ & $\mathbf{. 0 2 6 9 8}$ & $\mathbf{1 . 6 6 4 0}$ & $\mathbf{1 . 7 7 9 0}$ & $\mathbf{1 . 5 5}$ & $\mathbf{1 . 8 8}$ \\
\hline
\end{tabular}


Hasil penelitian dari pengaruh konsentrasi ekstrak daun sirih hijau (Piper betle L.) terhadap penyembuhan luka pada mencit (Mus musculus L.), menunjukkan persentase tingkat kesembuhan luka yang berbeda (Gambar 1). Kusuma (2016) menyebutkan bahwa penyembuhan luka meliputi jenis luka, konsentrasi obat yang diberikan, dan perawatan pada daerah luka.

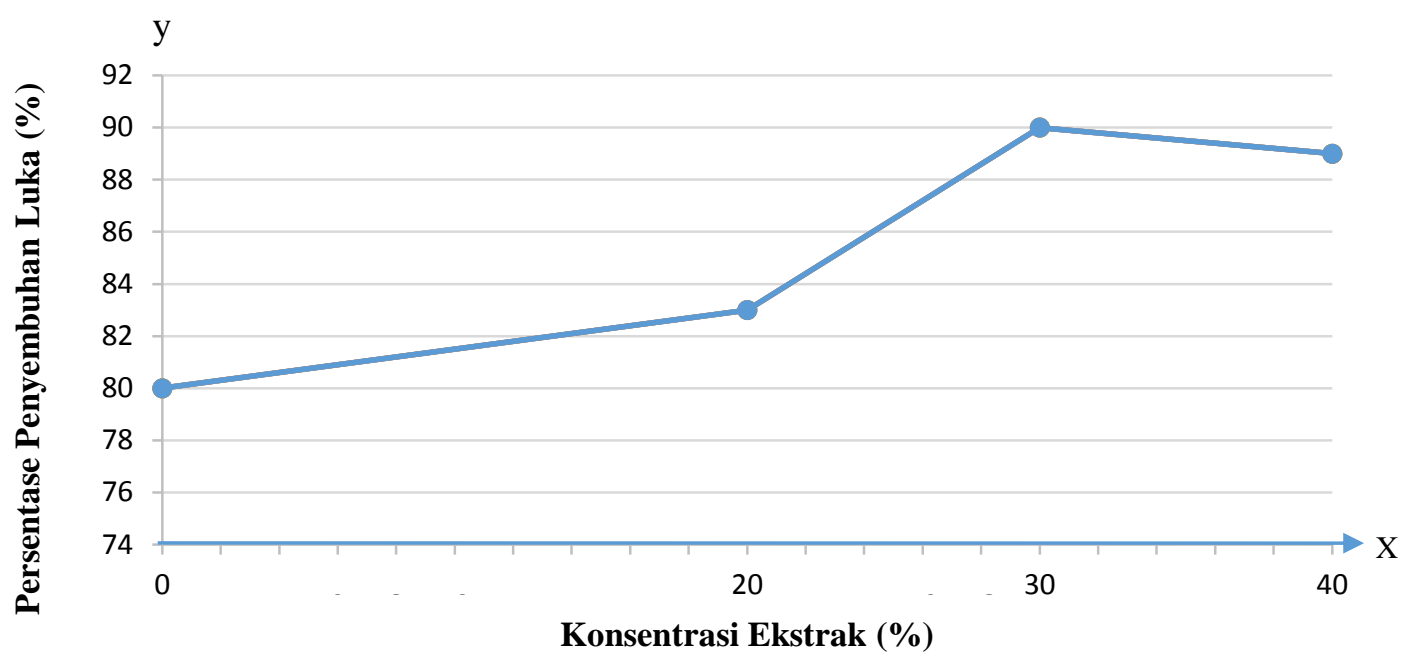

Gambar1. Persentase Kesembuhan Luka pada Mencit

Grafik diatas menjelaskan bahwa persentase kesembuhan luka yaitu pada perlakuan mencit (Mus musculus L.) yang diberikan aquades memiliki nilai rata-rata sebesar $1.601 \mathrm{~cm}$ dengan standar deviasi yaitu sebesar 05317 dengan persentase kesembuhan luka $80 \%$, selanjutnya untuk perlakuan mencit (Mus musculus L.) yang diberikan ekstrak 20\% memiliki nilai rata-rata sebesar $1.6509 \mathrm{~cm}$, dengan standar deviasi yaitu sebesar .03173 dengan persentase kesembuhan luka $83 \%$, untuk perlakuan mencit (Mus musculus L.) yang diberikan ekstrak $30 \%$. memiliki nilai rata-rata $1.8502 \mathrm{~cm}$, dengan standar deviasi yaitu .02205 dengan persentase kesembuhan luka 90\%. Sementara itu, mencit (Mus musculus L.) yang diberikan perlakuan ekstrak $40 \%$ memiliki nilai rata-rata sebesar $1.7836 \mathrm{~cm}$, dengan nilai standar deviasi yang diperoleh yaitu sebesar 10790 dengan persentase kesembuhan luka $89 \%$. Hasil análisis One Way Anova tentang pengaruh dari ekstrak daun sirih hijau (Piper betle L.) terhadap penyembuhan luka pada mencit (Mus musculus $L$.), seperti pada (Tabel 3).

Tabel 3. Hasil analisis One Way Anova konsentrasi bahan cairan daun sirih hijau terhadap tingkat penyembuhan luka dari hewan mencit kelompok eksperimen

\begin{tabular}{|c|c|c|c|c|c|}
\hline Nilai & $\begin{array}{c}\text { Sum of } \\
\text { Squares }\end{array}$ & Df & Mean Square & F & Sig. \\
\hline $\begin{array}{c}\text { Between } \\
\text { Groups }\end{array}$ & .159 & 3 & .053 & 41.445 & .000 \\
\hline Within Groups & .015 & 12 & .001 & & \\
\hline Total & $\mathbf{. 1 7 5}$ & $\mathbf{1 5}$ & & & \\
\hline
\end{tabular}


Data pada (Tabel 3) di atas menunjukkan bahwa nilai sig atau p-value diperoleh sebesar $0.000<0.05$ (pada taraf alfa 5\%). Hasil ini menunjukkan bahwa Ho ditolak maka dapat disimpulkan ada pengaruh ekstrak daun sirih hijau (Piper betle L.) terhadap penyembuhan luka pada mencit. karena pada ekstrak daun sirih hijau (Piper betle L.) terdapat kandungan alkaloid, flavonoid, steroid, saponin, dan tannin yang dapat menyembuhkan luka (Mawarti, 2016). Sejalan dengan penelitian Masir (2012) bahwa pada pada konsentrasi $30 \%$ dapat mempercepat penyembuhan luka dilihat dari diameter retriksi luka pada mencit (Mus musculus L.). Sementara itu, hasil uji lanjut dengan uji analisis uji Least Significance Differences (LSD) tentang pengaruh dari keempat perlakuan, seperti pada (Tabel 4).

Tabel 4. Hasil Uji LSD terhadap empat kelompok hewan perlakukan

\begin{tabular}{|c|c|c|c|}
\hline Kelompok Antar Perlakuan & $\begin{array}{c}\text { Mean } \\
\text { Difference }\end{array}$ & LSD & Keterangan \\
\hline Aquades dan ekstrak 20\% & $.06657^{\prime}$ & .022 & Signifikan/berbeda \\
\hline Aquades dan ekstrak 30\% & $.24875^{\prime}$ & .000 & Signifikan/berbeda \\
\hline Aquades dan ekstrak 40\% & $.19928^{\prime}$ & .000 & Signifikan/berbeda \\
\hline Ekstrak 20\% dan ekstrak 30\% & .18218 & .000 & Signifikan/berbeda \\
\hline Ekstrak 20\% dan ekstrak 40\% & .13272 & .000 & Signifikan/berbeda \\
\hline Ekstrak 30\% dan ekstrak 40\% & -.04946 & .074 & $\begin{array}{c}\text { Tidak } \\
\text { signifikan/sama }\end{array}$ \\
\hline
\end{tabular}

Penyembuhan luka adalah mengembalikan fungsi dan bentuk jaringan yang rusak agar jaringan kulit kembali normal dengan komplikasi lokal seminimal mungkin (Vina, 2011). Hasil analisis pada penelitian ini, dimana nilai sig atau $\mathrm{p}$ value diperoleh sebesar $0.000<0.05$ (pada taraf alfa 5\%) yang dapat menjelaskan bahwa ada pengaruh dari ekstrak daun sirih hijau (Piper betle L.) terhadap tingkat kesembuhan hewan uji (mencit). Hal ini, diduga akibat dari pengaruh kandungan alkaloid, flavonoid, steroid dan saponin yang berperan penting pada penyembuhan luka pada mencit (Mus musculus L.). Sejalan dengan penelitian Masir (2012) bahwa pada pada konsentrasi $30 \%$ dapat mempercepat penyembuhan luka dilihat dari diameter retriksi luka pada mencit (Mus musculus L.). Semakin sedikit nilai sig atau p-value yang diperoleh yaitu sebesar $0.000<0.05$ (pada taraf alfa 5\%) menandakan bahwa pengaruh penyembuhan luka semakin baik.

Sementara itu, dari data yang diperoleh terlihat bahwa kelompok kontrol mengalami pengaruh terhadap penyembuhan luka, hal ini disebabkan karena pada dasarnya setiap makhluk hidup memiliki kemampuan untuk mempertahankan diri atau dengan kata lain memiliki sistem imunitas. Menurut Baratawidjaja (2009) imunitas adalah sistem mekanisme pada organisme yang melindungi tubuh terhadap pengaruh biologis luar dengan mengidentifikasi dan membunuh patogen. Sistem ini mendeteksi berbagai macam pengaruh biologis luar yang luas, organisme akan melindungi tubuh dari infeksi, bakteri, virus, sampai cacing parasit, serta menghancurkan zat-zat asing lain dan memusnahkan mereka dari sel organisme yang sehat dan jaringan agar tetap dapat berfungsi seperti biasa.

Senyawa yang memiliki keefektifan untuk dapat menyembuhkan luka atau penyakit berasal dari senyawa metabolit sekunder. Daun sirih hijau (Piper betle L.) mengandung senyawa metabolit sekunder yaitu alkaloid, flavonoid, steroid, terpenoid, saponin, tanin. Selain itu, terkandung juga fenol, dan steroid, minyak atsiri, terpinen, 
seskuiterpen, fenilpropan, dan terpen (Depkes RI, 1980). Flavonoid merupakan salah satu golongan fenol alam yang terbesar. Sebenarnya, flavonoid terdapat dalam semua tanaman hijau dan dalam tanaman aglikon flavonoid (yaitu flavonoid tanpa gula terikat) terdapat dalam berbagai bentuk struktur. Semuanya mengandung 15 atom karbon dalam inti dasarnya, yang tersusun dalam konfigurasi C6-C3-C6, yaitu dua cincin aromatik yang dihubungkan oleh satuan tiga karbon.

Flavonoid adalah senyawa polar karena memiliki sejumlah gugus hidroksil yang tidak terdistribusi. Pelarut polar seperti etanol, metanol, etil asetat, atau campuran dari pelarut tersebut dapat digunakan untuk mengekstrak flavonoid dari jaringan tumbuhan. Pengambilan bahan aktif dari suatu tanaman dapat dilakukan dengan ekstraksi. Dalam proses ekstraksi ini bahan aktif akan terlarut oleh zat yang sesuai sifat kepolarannya. Flavonoid termasuk salah satu kelompok senyawa metabolit sekunder yang paling banyak ditemukan di dalam jaringan tanaman (Rajalakshmi, 1985). Flavonoid berperan sebagai antioksidan dengan cara mendonasikan atom hidrogennya atau melalui kemampuannya mengkelat logam, berada dalam bentuk glukosida (mengandung rantai samping glukosa) atau dalam bentuk bebas yang disebut aglikon (Cuppett, 1954). Flavonoid mempunyai komposisi 90\% Diosi dan 10\% hespiridin, dimana mempunyai efek meningkatkan vaskularisasi dan proteksi pada endotelium vaskular. Dari hasil studi klinik dan eksperimen flavonoid dapat meningkatkan vaskularisasi dan menurunkan edema. Pada penelitian terbaru 0leh Mawarti (2016) membuktikan bahwa flavonoid mempunyai efek antiinflamasi dan antioksidan. Kandungan flavonoid juga diyakini mempunyai manfaat dalam proses penyembuhan luka (Acar et al., 2002).

Efek antioksidan ditunjukan dari kandungan yang terdapat dalam flavonoid yaitu adanya caffeic acid phenetyl ester (CAPE) yang merupakan antioksidan tingkat tinggi (Pakorny et al., 2001). Menurut Geoffrey and Sabine (2008) dalam penelitiannya tentang ekstrak propolis green brazillian dan penyembuhan luka didapatkan hasil terdapat kandungan caffeolylguinic acid dan cinnamic acid yang merupakan (derivat pcoumaric acid, bacharin, drupamin dan artepillin C) keduanya mempunyai aktivitas biologis sebagai antimikroba, anti tumor, antioksidan, apoptosis inducer dan imunomodulator. Mekanisme proses penyembuhan luka difokuskan pada 3 area yaitu yang pertama adanya ekspresi dari sitokin dan hormonal pada saat penyembuhan luka, yang kedua melibatkan peran dan fungsi dari Nitric Oxide (NO) dalam proses penyembuhan luka, dan yang ketiga adalah regulasi dari metabolisme kolagen dalam perbaikan jaringan (Subrahmanyam et al., 2001). Tanaman yang mengandung senyawa flavonoid dapat digunakan sebagai antikanker, antioksidan, antiinflamasi, antialergi, dan antihipertensi (Fauziah, 2010).

Antioksidan adalah zat penghambat reaksi oksidasi akibat radikal bebas yang dapat menyebabkan kerusakan asam lemak tak jenuh, membran dinding sel, pembuluh darah, basa DNA, dan jaringan lipid sehingga menimbulkan penyakit. Suatu tanaman dapat memiliki aktivitas antioksidan apabila mengandung senyawa yang mampu menangkal radikal bebas seperti fenol dan flavonoid. Ekstrak daun sirih mengandung senyawa alkaloid, flavonoid, steroid dan saponin dengan kadarnya yang standar. Senyawa ini diduga bekerja sama saling menguatkan, diantara senyawa-senyawa tersebut steroid merupakan senyawa yang lebih banyak ditemukan sedangkan senyawa alkaloid hanya pada satu pereaksi dinyatakan positif terkandung dalam ekstrak. Senyawa alkaloid yang berjumlah sedikit juga berperan sebagai antimikroba melalui mekanisme kerjanya yang berhubungan dengan kemampuan untuk berinteraksi dengan DNA bakteri (Puetri, 2015).

Polifenol merupakan senyawa turunan fenol yang mempunyai aktivitas sebagai antioksidan. Antioksidan fenolik biasanya digunakan untuk mencegah kerusakan atau keadaan yang kurang dari normal. Polifenol 
mampu mengurangi stress oksidatif dengan cara mencegah terjadinya reaksi berantai pengubahan superoksida menjadi hidrogen superoksida menjadi hidrogen superoksida dengan mendonorkan atom hidrogen dari kelompok aromatik hidroksil (-OH) polifenol untuk mengikat radikal bebas dan membuangnya dari dalam tubuh melalui sistem ekskresi. Menurut Wardhana (2010) meningkatnya stress oksidatif diakibatkan karena homeostasis metabolisme terganggu misalnya hiperglikemia, dislipidemia, dan kadar asam lemak yang tinggi. Tanin tersebar dalam setiap tanaman yang berbatang. Tanin berada dalam jumlah tertentu, biasanya berada pada bagian yang spesifik tanaman seperti daun, buah, akar dan batang. Tanin merupakan senyawa kompleks, biasanya merupakan campuran polifenol yang sukar untuk dipisahkan karena tidak dalam bentuk Kristal. Tanin biasanya berupa senyawa amorf, higroskopis, berwarna coklat kuning yang larut dalam organik yang polar. Tanin mempunyai aktivitas antioksidan menghambat pertumbuhan tumor dan enzim. Hasil penelitian oleh Rohmawati (2008) menyebutkan bahwa tanin mempunyai daya antiseptik yaitu mencegah kerusakan yang disebabkan bakteri atau jamur.

Penelitian ini menggunakan tiga konsentrasi untuk tiga kelompok perlakuan dengan ekstrak daun sirih hijau (Piper betle L.) yaitu dengan konsentrasi $20 \%, 30 \%$, dan $40 \%$, serta satu kelompok kontrol dengan $14 \mathrm{x}$ pengukuran diameter luka atau 14 hari, sejalan dengan penelitian Mawarti (2016) bahwa penyembuhan luka pada hari ke 14 sudah menunjukkan perbedaan diameter luka, bahkan lama penyembuhan luka pada mencit (Mus musculus L.). Hal ini dilakukan untuk mengetahui konsentrasi yang efektif untuk penyembuhan luka pada mencit (Mus musculus L.). Hasil uji Anova one way menunjukkan bahwa terdapat pengaruh ekstrak daun sirih hijau (Piper betle L.) terhadap penyembuhan luka pada mencit. Konsentrasi $30 \%$ dari ekstrak daun sirih hijau (Piper betle L.) yang digunakan oleh peneliti sudah layak digunakan sebagai obat untuk menyembuhkan luka. Maka dari itu untuk mengetahui pengaruh antar keempat perlakuan tersebut dapat dilakukan dengan melakukan uji lanjut menggunakan uji BNT atau LSD. Sehingga diperoleh hasil bahwa diberikan aquades - ekstrak 20\% signifikan/berbeda karena nilai sig $0.022<0.05$, diberikan aquades - ekstrak $30 \%$ signifikan/berbeda karena nilai sig $0.000<$ 0.05 , diberikan aquades - ekstrak $40 \%$ signifikan/berbeda karena nilai sig $0.000<0.05$ ekstrak 20\% - ekstrak 30\% signifikan/berbeda karena nilai sig $0.000<0.05$ ekstrak $20 \%$ - ekstrak $40 \%$ signifikan/berbeda karena nilai sig $0.000<$ 0.05 , dan ekstrak 30\% - ekstrak $40 \%$ tidak signifikan/sama karena nilai sig $0.074>0.05$ yang menandakan bahwa tidak ada perbedaan atau perubahan yang terjadi pada mencit apabila diberikan ekstrak $30 \%$ atau $40 \%$.

Penyembuhan luka terkait dengan regenerasi sel sampai fungsi organ tubuh kembali pulih ditunjukkan dengan tanda tanda dan respon yang berurutan dimana sel secara bersama-sama berinteraksi, melakukan tugas dan berfungsi secara normal. Idealnya luka yang sembuh kembali normal secara struktur anatomi, fungsi, dan penampilan. Pada hari ke 14x pengamatan, hewan uji sudah bisa berinteraksi secara normal kembali. Dilihat dari tingkah laku mencit (Mus musculus L.) bisa bermain-main di kandang, dapat mengkonsumsi makanan dan minum dengan porsi yang banyak.

\section{Kesimpulan}

Ekstrak daun sirih hijau (Piper betle L.) berpengaruh terhadap penyembuhan luka pada mencit (Mus musculus L.). Konsentrasi 30\% lebih berpengaruh terhadap penggunaan sebagai obat luka dari pada konsentrasi yang lain.

\section{Ucapan Terima Kasih}

Penelitian ini dapat dilaksanakan dengan baik berkat bantuan dari berbagai pihak, oleh sebab itu peneliti mengucapkan terima kasih kepada Dosen Pembimbing, Pegawai laboratorium, dan teman-teman yang telah membantu.

\section{Referensi}


Acar, Tcylidiz. R. \& Arcliz, K. L. (2002). Efficasnsy of Micronized Flavonoid Fraction on Healing in Thermally Injured Rat. Jurnal Amal of Burns and Fire Disasters, 2(1): 22-63.

Baratawidjaja K, \& Rengganis I. (2009). Imunologi Dasar, Edisi Kedelapan. Jakarta: Balai Penerbit Fakultas Kedokteran Indonesia.

Depkes RI. (1980). Materia Medika Indonesia Jilid IV. Jakarta: Departemen Kesehatan Republik Indonesia.

Fransius (2008). Penampilan Reproduksi Mencit (Mus musculus) yang Diberi Daun Torbangun (Coleus amboinicuslour) dan Taraf Sop Daun Torbangun Kering. Jurnal Biodiversitas, 4(1): 14-86.

Geoffrey, Gufter, and Sabine, Werner (2008). Wound Repair and Regeneratin. Jurnal Nature London, 2(4): 93-267.

Gitarja, W.S. (2008). Perawatan Luka Diabetes. Bogor: Wocare Publishing.

Haki, M. (2009). Efek ekstrak daun talok (Muntinga calabura L.) terhadap aktivitas enzim sgpt pada mencit yang diinduksi karbon tetraklorida.

Hasibuan, M. T. D. (2018). Hubungan Status Nutrisi dengan WaktuPenyembuhan Luka pada Pasien Post Apendiktomi di Rumah Sakit Kota Medan. Jurnal Ilmiah Keperawatan Imelda. 4(1), 427-430.

Hidayat, I. R.S., Napitupulu, R. M., \& SP, M. (2015). Kitab Tumbuhan Obat AgriFlo.

Kusuma, R. F., Ranawa, R., \& SL, D.D. (2016). Pengaruh perawatan luka bakar derajat II menggunakan ekstrak etanol daun sirih (Piper betle Linn.) terhadap peningkatan ketebalan Jaringan granulasi pada tikus putih (Rattus norvegicus) jantan galur wasir. Majalah Kesehatan FKUB, 1 (2), 86-94.
Masir, O., Manjas, M., Putra, A.E., \& Agus, S. (2012). Pengaruh Cairan Cultur Filtrate Fibroblast (CFF) Terhadap Penyembuhan Luka; Penelitian Eksperimental pada Rattus norvegicus Galur Wistar. Jurnal Kesehatan Andalas, 1(3): 24-93.

Mawarti, \& Herin. N. (2016). Pengaruh Flavonoid Propolis Terhadap Lama Penyembuhan Luka Bakar Grade Ii Pada Tikus Putih. Jurnal Kesehatan. Andalas, 2(1): 127-251.

Oswald, T. T. (1981). Tumbuhan Obat. Jakarta: Bahratara Karya Aksara.

Pakorny, Michael. Gordon. W. \& Zerny. K. (2001). Antioksidant in Food. Woodhead Published. USA: ITD and CRC.

Prayoga, E. (2013). Perbandingan efek ekstrak daun sirih hijau (Piper batle L.) dengan metode difusi disk dan sumuran terhadap pertumbuhan bakeri Staphylococcus aureus.

Puetri, Nona (2015). Pengaruh Pemberian Ekstrak Daun Sirih (Piper betle L.) Terhadap Pertumbuhan Staphylococcus aureus Isolat dari Penderita Faringitis. Jurnal Biodiversitas Biologi, 2(2): 57-65.

Putri, Z. F. (2010). Uji Aktivitas Antibakteri Ekstrak Etanol Daun Sirih (Piper betle L.) Terhadap Propioni bacterium acne dan Staphylococcus aureus Multiresisten. Jurnal MIPA, 12(1): 92-347.

Rajalaksmi, D \& S, Narasimhan. (1985). Food Antioxidants: Sources and Methods of Evaluation dalam D.L Madhavi: Food Antioxidant, Technological, Toxilogical and Health Perspectives. Jurnal Marcel Dekker, 4(1):76-77.

Rohmawati, Nina. (2008). Efek Penyembuhan Luka Bakar dalam Sediaan Gel Ekstrak Etanol 70\% Daun Lidah Buaya (Aloe vera L.) pada Kulit Punggung Kelinci New Zealand. Jurnal Kesehatan, 5(2): 51-172.

Subrahmanyam, M. Sahapure., \& A. Rand. N. (2001). Effects of Topical Application of 
Zar'ah, NA. et al. (2021). Jurnal Biologi Tropis, 21 (1): 103 - 111

DOI: http://dx.doi.org/10.29303/jbt.v21i1.2282

Honey on Burn Wound Healing. Jurnal Annals of Burns and Fire Disasters, 14(3): 35-254.

Suratman, Sumiwi, S.A., \& Gozali, D., (1996). Pengaruh Ekstrak Antanan dalam Bentuk Salep, Krim dan Jelly terhadap Penyembuhan Luka Bakar, Jakarta: Cermin Dunia Kedokteran.
Vinna, K. S. (2011). Peningkatan Penyembuhan Luka di Mukosa Oral Melalui Pemberian Aloe Vera (Linn.) Secara Topikal. Jurnal $J K M, 11(1): 70-79$.

Wardahana, P. N. (2010). Efek Anthigliperikemik Ekstrak Daun Sirih Merah (Piper crocatum) pada Tikus Putih (Rattus novergius). Jurnal Kesehatan, 16(2): 127-304. 